\title{
Berkjuskúlk - yfirlit
}

\section{Gunnar Guð̌mundsson $n^{1,2}$ læknir Gunnar Júlíusson³ læknir}

\author{
'Lungnadeild Landspítala, ${ }^{2}$ læknadeild Háskóla Íslands, ${ }^{3}$ röntgendeild Karólínska \\ Háskólasjúkrahúsins í Stokkhólmi. Svípjóð.
}

Fyrirspurnum svarar Gunnar Guðmundsson, ggudmund@landspitali.is

\section{Inngangur}

Berkjuskúlk (Bronchiectasis) er sjúkdómur par sem berkjur verða óeðlilega víðar og um er að ræða ástand sem að jafnaði gengur ekki til baka. ${ }^{1}$ Petta getur verið staðbundið eða dreift um lungun. Sjúkdómurinn kemur fyrir bæði hjá börnum og fullorðnum og einkennist af hósta með uppgangi og endurteknum sýkingum. ${ }^{2}$ Hann einkennist af endurteknum tímabilum par sem einkenni versna mikið og gerist pað oftast vegna sýkinga. ${ }^{3}$ Algengt er að bakteríur ræktist úr hrákasýni bæði í stöðugu ástandi og við versnanir.

Berkjuskúlk er oftast af ópekktum orsökum en getur tengst fjöldamörgum sjúkdómum bæði í lungum og utan peirra. Í lungum má nefna astma, langvinna lungnateppu, og utan peirra gigtsjúkdóma eins og liðagigt, bólgusjúkdóma í meltingarvegi og ónæmisgalla. Pannig verður sjúkdómsmyndin ólík milli einstaklinga pví berkjuskúlk er í raun lokaútkoma margra sjúkdómsferla. Slímseigjusjúkdómur í lungum (cystic fibrosis) er einn peirra lungnasjúkdóma sem veldur berkjuskúlki. Ekki verður fjallað frekar um hann í pessu yfirliti heldur aðrar orsakir.

Greining fæst með tölvusneiðmynd af lungum til viðbótar við klínísk einkenni. Myndgreining sýnir útvíkkaðar berkjur en gefur einnig vísbendingar um aðra sjúkdóma í lungum. ${ }^{4}$ Pannig getur staðsetning berkjuskúlks til viðbótar öðrum breytingum greint orsakir í sumum tilvikum

Uppvinnsla til að greina aðrar sjúkdóma sem hafa tengsl við berkjuskúlk er mikilvæg og er mismunandi eftir aldri sjúklings og almennu ástandi hans. Sjúklingar með berkjuskúlk hafa skert heilsutengd lífsgæði og styttar lífslíkur. ${ }^{5}$

Meðferð er fólgin í meðhöndlun undirliggjandi sjúkdóma, sýklalyfjum og loftvegahreinsun. ${ }^{6}$ Einnig er ýmis sérhæfð meðferð í boði fyrir hluta pessara sjúklinga og ræðst af undirliggjandi orsök.7 Í pessari grein verður gefið yfirlit um berkjuskúlk sem nýtist mörgum læknum í daglegu starfi pví sjúkdómurinn greinist víða,

\section{Á G R I P}

Berkjuskúlk er sjúkdómur par sem berkjur verða óeðlilega víðar og um er að ræða viðvarandi ástand. Petta getur verið staðbundið eða dreift um bæđi lungu. Sjúkdómurinn kemur á öllum aldri og veldur hósta međ uppgangi og endurteknum sýkingum. Tíoni er hærri hjá konum og vex með aldri. Hann einkennist af endurteknum tímabilum par sem einkenni versna mikið og gerist pað oftast vegna sýkinga.

Berkjuskúlk getur verið af ópekktum orsökum en getur tengst fjöldamörgum sjúkdómum bæði i lungum og utan peirra. Sem dæmi um slíka sjúkdóma eru astmi, langvinn lungnateppa og liðagigt auk pess sem brestir í ónæmiskerfi tengjast berkjuskúlki. Pannig er sjúkdómsmynd ólík milli einstaklinga.

Greining fæst með tölvusneiðmynd af lungum til viðbótar við klínísk einkenni. Uppvinnsla til að greina aðra sjúkdóma sem hafa tengsl við berkjuskúlk er mikilvæg. Í pví sambandi er sögutaka, líkamsskoðun og frekari rannsóknir mikilvægar.

Sjúklingar með berkjuskúlk hafa skert heilsutengd lífsgæði og styttar lífslíkur. Meðferð er fólgin í meðferð undirliggjandi sjúkdóma, sýklalyfjum og loftvegahreinsun. Lungnaendurhæfing og reglulegt eftirlit eru einnig mikilvæg.

Í pessari grein verður gefið yfirlit um berkjuskúlk sem nýtist mörgum læknum í daglegu starfi pví sjúkdómurinn sést víða, bæđi hjá heimilislæknum, á sjúkrahúsum og utan sjúkrahúsa.

\section{Skúlk}

Orðið skúlk er hvorugkynsnafnorð og er á ensku ectasis og á latínu ectasia. Petta er gamalt orð í íslensku sem talið er merkja hnúsk, bungu eða bólgu. Í daglegu tali við sjúklinga er betra að tala um útvíkkaðar berkjur. 
bæði hjá heimilislæknum, á sjúkrahúsum og utan sjúkrahúsa. Pá er einnig mikilvægt að röntgenlæknar lýsi berkjuskúlki ef pað sést á myndgreiningarrannsóknum.

\section{Skilgreining og faraldsfræði}

Berkjuskúlk er skilgreint sem útvíkkun á berkjum lungnanna sem að jafnaði gengur ekki til baka. Greining fæst fram með tölvusneiðmynd af brjóstholi. ${ }^{4}$ Ekki er nein ein orsök fyrir berkjuskúlki heldur eru pær fjöldamargar og berkjuskúlk pannig lokaútkoma margra sjúkdómsferla. ${ }^{8,9}$ Klínísk einkenni eru hósti, slímuppgangur og endurteknar öndunarfærasýkingar. ${ }^{10}$ Algengi er talið vera um 500/100.000 og er heldur hærra hjá konum en körlum. ${ }^{11,12}$ Berkjuskúlk getur sést bæði hjá börnum og fullorðnum og tíðni eykst með vaxandi aldri. ${ }^{13,14}$ Sjúkdómurinn veldur skertum heilsutengdum lífsgæðum og eykur dánartíðni. ${ }^{1}$

\section{Meingerð}

Meingerð berkjuskúlks er ekki vel pekkt. Mest hefur verið lagt upp úr kenningu um vítahring sem Cole lagði fram varðandi tilurð og frampróun berkjuskúlks. ${ }^{15}$ Í honum er gert ráð fyrir að fjórir mismunandi pættir hafi áhrif. Peir eru skertar varnir lungna, bólgusvörun, skemmdir á loftvegum og sýking, eins og sést á mynd 1. Upphafspunkturinn er mismunandi eftir pví hvað veldur berkjuskúlki. Pannig eru peir sem hafa meðfædda eða áunna ónæmisgalla með skertar lungnavarnir sem leiða til sýkinga. Bólgusjúkdómar í lungum og liðagigt auka á bólgusvörun í lungum. Endurtekin ásvelging veldur beinum vefjaskaða. Sýkingar geta valdið vefjaskaða og aukið á bólgusvörun. Sumir sjúkdómar geta haft áhrif á fleiri en einn pátt. ${ }^{15}$

Berkjuskúlk er talinn langvinnur bólgusjúkdómur par sem einkum sést berkjubólga með daufkirningum. ${ }^{16}$ Aukinn fjöldi peirra sést bæði í stöðugu ástandi og við versnanir. ${ }^{17}$ Peir sem eru með viðvarandi bakteríusýkingar hafa enn fleiri daufkirninga en peir sem ekki eru sýktir. Starfsemi daufkirninganna er skert. ${ }^{18}$ Pannig er sjálfdrepi seinkað hjá peim og frumuát er skert. ${ }^{19}$ Daufkirningarnir hafa aukna úrkornun sem veldur pví að prótínkljúfar eru losaðir og pað leiðir til vefjaskemmda. ${ }^{16}$ Fjölgun verður á slímmyndandi kirtlum og starfsemi peirra eykst. ${ }^{20}$ Magn prótínkljúfa eykst með vaxandi fjölda baktería í berkjum og eykst einnig við versnanir. ${ }^{21}$ Hluti peirra sem hafa berkjuskúlk eru með aukningu á rauðkirningum í berkjum. ${ }^{19}$ Vaxandi pekking á hlutverki D-vítamíns í vörnum líkamans hefur komið fram á liðnum árum. ${ }^{22}$ D-vítamín dregur úr myndun á bólguaukandi frumuhvötum og eykur áhrif sýkladrepandi peptíða. ${ }^{23}$ Rannsóknir hafa sýnt að algengt er að sjúklingar með berkjuskúlk séu með skort á D-vítamíni og hann tengist meiri sýklabyrði í berkjunum, lægri gildum í öndunarmælingum og meiri lækkun á öndunarmælingum yfir tímabil. ${ }^{24}$

\section{Klínísk einkenni}

Algengustu einkenni sjúklinga með berkjuskúlk eru hósti og slímuppgangur. Stundum er hóstinn purr. Pá getur fylgt mæði og slappleiki. Blóðhósti getur komið fyrir sem og brjóstverkir og surg fyrir brjósti. ${ }^{1}$ Endurteknar öndunarfærasýkingar eru eitt af

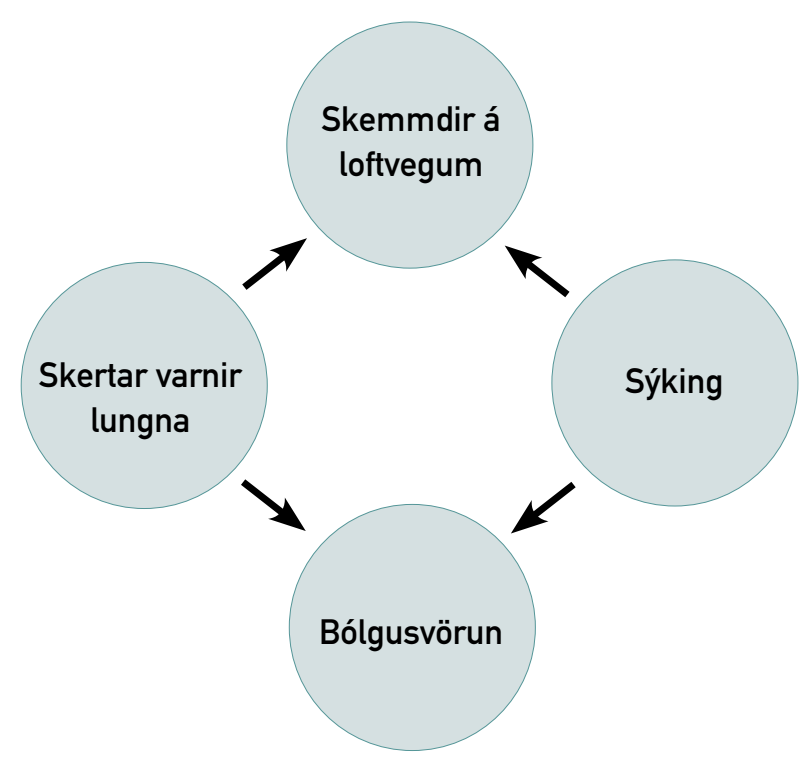

Mynd 1. Líta má á meingerð̉ berkjuskúlks sem vítahring, sjá nánar í texta.

megineinkennum berkjuskúlks en eru ekki til staðar hjá öllum. Líkt og í mörgum öðrum lungnasjúkdómum koma endurteknar versnanir á einkennum pótt pað gerist misoft og stundum mjög sjaldan. ${ }^{20}$ Hafa ætti berkjuskúlk í huga hjá sjúklingum sem hafa langdreginn hósta (lengur en 8 vikur) með eða án slímuppgangs. Mikilvægt er að leita í sögutöku að einkennum sjúkdóma sem geta tengst berkjuskúlki. ${ }^{25}$ Pá er einnig mikilvægt að kanna með fyrri sýkingar, allt frá barnæsku. Pá er gott að spyrja hvort kyngingarerfiðleikar séu til staðar. Við líkamsskoðun er mikilvægt að leita að teiknum um aðra sjúkdóma sem tengjast berkjuskúlki. Við lungnahlustun geta heyrst brakhljóð pótt ekki sé pað algilt og mælingar á súrefnismettun geta sýnt súrefnisskort í langt gengnum sjúkdómi eða við versnanir. ${ }^{26}$

\section{Sýklafræði}

Sýkingar eru einn af meginpáttum berkjuskúlks, bæði í stöðugu ástandi og pegar ástand versnar. ${ }^{20}$ Bakteríusýkingar eru algengar. ${ }^{27}$ Með hefðbundnum ræktunum á hráka er algengt að greina $P$. aeruginosa og $H$. influenzae. Aðrar bakteríur sem ræktast úr hráka eru Moraxella catarrhalis, Staphylococcus aureus, Streptococcus pneumoniae, Klebsiella-tegundir og Escherichia-tegundir. Pá finnast einnig mýkóbakteríur sem ekki eru berklar. ${ }^{28}$

Í norðurhluta Evrópu er $H$. influenzae algengust en í SuðurEvrópu er $P$. aeruginosa algengari. ${ }^{29}$ Pessar bakteríur finnast einnig oftast í Asíu. ${ }^{30}$ Í Bandaríkjunum er mun algengara að sjúklingar séu sýktir af mýkóbakteríum sem ekki eru berklar. Skýring á pessu getur að hluta til verið að sérhæfðar miðstöðvar í Bandaríkjunum leggja sig sérstaklega fram við greiningu og meðferð sýkinga sem eru af völdum mýkóbaktería sem ekki eru berklar og birta niðurstöður sínar í vísindatímaritum. ${ }^{31}$ Par er algengast að finna Mycobacterium avium, M. abscessus og M. chelonae.

Lítið er vitað um hversu algengar veiru- og sveppasýkingar eru í berkjuskúlki. ${ }^{1}$ Algengast er að rækta Aspergillus-tegundir. Pegar einkenni aukast er oftast að finna sömu bakteríutegundir og eru til staðar í stöðugu ástandi. ${ }^{32}$ Pannig er talið að meiri vöxtur verði 
á peim bakteríum sem fyrir eru en einnig að nýjar tegundir geti myndast. Veirusýkingar eru algengari í versnunum, sérstaklega að vetrarlagi, en mun minni upplýsingar eru til um veirusýkingar í berkjuskúlki en í öðrum lungnasjúkdómum, til dæmis astma og langvinnri lungnateppu. ${ }^{20,33}$ Engar upplýsingar eru til um sýklafræði berkjuskúlks á Íslandi.

Raðgreiningar á DNA hafa aukið mikið pekkingu okkar á sýklafræði lungna á síðustu árum. ${ }^{34}$ Pannig hefur verið vel lýst heilbrigðu örverumengi (microbiome) í lungum, sem áður voru talin án sýkla. Í berkjuskúlki sést nokkur munur á hrákaræktunum og raðgreiningu á DNA..$^{35}$ Pannig virðist minna koma fram af $H$. influenzae og $M$. catarrhalis í hefðbundnum ræktunum en meira af $P$. aeruginosa og S. aureus. Fjöldamargar rannsóknir hafa sýnt að meðferð með sýklalyfjum hefur einungis skammvinn áhrif á örverumengi í öndunarfærum. ${ }^{20}$ Versnanir virðast tilkomnar vegna breytingar í hegðun sýkla frekar en að sýklasamsetning breytist. ${ }^{20}$

\section{Sjúkdómar sem tengjast berkjuskúlki}

Fjöldamargir sjúkdómar tengjast berkjuskúlki. ${ }^{26}$ Peir geta verið í brjóstholi eða utan brjósthols og stundum er um að ræða kerfissjúkdóma eins og sést í töflu I. ${ }^{36}$ Algengustu sjúkdómar í brjóstholi sem tengjast berkjuskúlki eru astmi (allt að 25\% með berkjuskúlk) og langvinn lungnateppa par sem allt að helmingur er með berkjuskúlk. ${ }^{37}$

Í langvinnri lungnateppu eykur berkjuskúlk fjölda versnana, dregur úr lungnastarfsemi og eykur dánartíðni. ${ }^{38}$ Berkjuskúlk kemur einnig fram hjá sjúklingum með alfa-1-antitrypsin skort og er ein af sjúkdómsmyndum slímseigjusjúkdóms. ${ }^{1}$ Par sem slím- seigjusjúkdómur hefur einstaka birtingarmynd og meðferðir er yfirleitt fjallað sérstaklega um berkjuskúlk í slímseigjusjúkdómi. ${ }^{39}$ Раð sama er gert í pessu yfirliti og ekki verður fjallað frekar um slímseigjusjúkdóm hér. Ofnæmissvörun könnusvepps í berkjum og lungum (allergic bronchopulmonary aspergillosis, ABPA) er ein af orsökum berkjuskúlks og tengist astma. ${ }^{40}$ Berkjuskúlk er oft hluti af lungnaskemmdum sem geta átt sér ýmsar orsakir. Sem dæmi getur geislameðferð vegna brjóstakrabbameins leitt til bandvefsmyndunar með meðfylgjandi berkjuskúlki. Рað sama á við sjúkdóma eins og sarklíki par sem sjúkdómurinn próast oft með tímanum í bandvefsmyndun og berkjuskúlk.

Endurtekin ásvelging getur valdið skemmdum á berkjum sem leiða til útvíkkunar peirra. Aðskotahlutir í berkjum koma af stað sýkingum og bólgusvörun sem mynda staðbundið berkjuskúlk. Sjúkdómar í bifhárum valda berkjuskúlki. Algengustu gigtarsjúkdómar sem tengjast berkjuskúlki eru liðagigt par sem berkjuskúlk hefur fundist í allt að helmingi sjúklinga. ${ }^{41}$ Í sumum tilfellum kemur berkjuskúlk fram á undan öðrum einkennum liðagigtar. Aðrir gigtarsjúkdómar sem tengjast berkjuskúlki eru heilkenni Sjögrens, heilkenni Marfans, herslismein, rauðir úlfar og hrygggikt. ${ }^{1,42}$ Ýmsir bólgusjúkdómar tengjast berkjuskúlki eins og bólgusjúkdómar í pörmum. ${ }^{43}$ Berkjuskúlk kemur einnig fyrir í sjúklingum með HIV-sýkingu. ${ }^{44}$

Pá geta fyrri sýkingar í lungum valdið berkjuskúlki og geta liðið áratugir frá pví að pað gerist og par til einkenni berkjuskúlks koma fram. Sýkingar í nefi og afholum pess tengjast berkjuskúlki. Meðfædd og áunnin ónæmisbilun getur valdið berkjuskúlki. Meðal peirra sjúkdóma sem eru meðfæddir og valda vanstarfsemi á ónæmiskerfinu er frumkominn ónæmisbrestur auk fleiri sjúk-

Tafla I. Orsakir berkjuskúlks, tíoni og greiningarrannsóknir. ${ }^{10}$

\begin{tabular}{|c|c|c|c|}
\hline Sjúkdómar í brjóstholi & Tíðni \% & Athugasemdir & Rannsóknir til greiningar \\
\hline Astmi & $17-43$ & Meta hvort gæti haft áunninn ónæmisbrest & Öndunarpróf. NO í útöndunarlofti, berkjuauðreitnipróf \\
\hline $\begin{array}{l}\text { Ofnæmissvörun könnusvepps } \\
\text { í berkjum og lungum }\end{array}$ & $1-7$ & Tengist astma & Ónæmisglóbúlin af E gerð, fellimótefni gegn Aspergillus. \\
\hline Langvinn lungnateppa & 4-69 & Meta hvort gæti haft áunninn ónæmisbrest & Öndunarpróf, merki um lungnapembu á tölvusneiðmynd \\
\hline Í kjölfar sýkingar & $33-42$ & Nákvæm sögutaka mikilvæg & Tölvusneiðmynd getur sýnt kalkanir og bandvef \\
\hline Ásvelging & $2-4$ & Einkenni tengjast máltídum & $\begin{array}{l}\text { Kyngingarmynd talmeinafræðings, röntgenmynd af vélinda, } \\
\text { vélindaspeglun }\end{array}$ \\
\hline Lungnaskemmdir & $2-4$ & Aðskotahlutur, geislun, bandvefur & Berkjuspeglun ef grunur um aðskotahlut \\
\hline \multicolumn{4}{|l|}{ Sjúkdómar sem ná til fleiri líffæra } \\
\hline Gigtarsjúkdómar & $3-6$ & Liðagigt, herslismein, heilkenni Sjögrens & Gigtarpróf, nákvæm líkamsskoðun \\
\hline $\begin{array}{l}\text { Bólgusjúkdómar í } \\
\text { meltingarfærum }\end{array}$ & $1-2$ & Sjúkrasaga um meltingarfæraeinkenni & Ristilspeglun \\
\hline Sýkingar & $1-34$ & $\begin{array}{l}\text { Mýkóbakteríur - ekki berklar, } \\
\text { HIV-sýking }\end{array}$ & $\begin{array}{l}\text { Berklaræktun á hráka, } \\
\text { mótefnamæling í blóði }\end{array}$ \\
\hline Ónæmisbrestir & $1-8$ & Meðfæddir og ánunnir & Ónæmisglóbúlin af $\lg A-, \lg M-$ og lgG-gerð auk undirflokka $\lg G$ \\
\hline Annað & $1-17$ & Bifhárasjúkdómar & Sýnataka frá nefi \\
\hline Ópekkt orsök & $30-53$ & Ef ekkert af ofangreindu finnst eftir uppvinnslu & \\
\hline
\end{tabular}




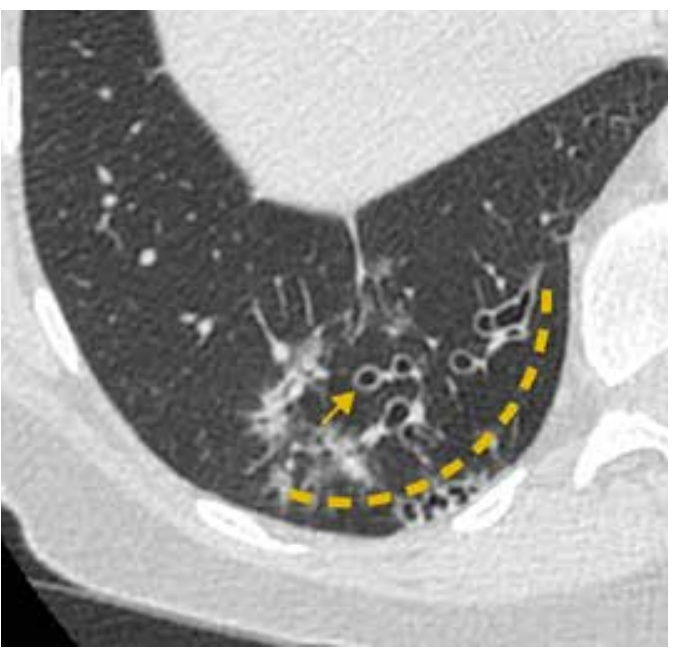

Mynd 2. Berkjuskúlk í hægra neðra lungnablaði. Berkjurnar eru víkkaðar samanborið við aðlæga lungnaslagæð (ör). Loftvegir eru einnig sýnilegir í minna en $1 \mathrm{~cm}$ fjarlægð frá rifjafleiðru (afmarkað af punktalinu). ${ }^{4}$
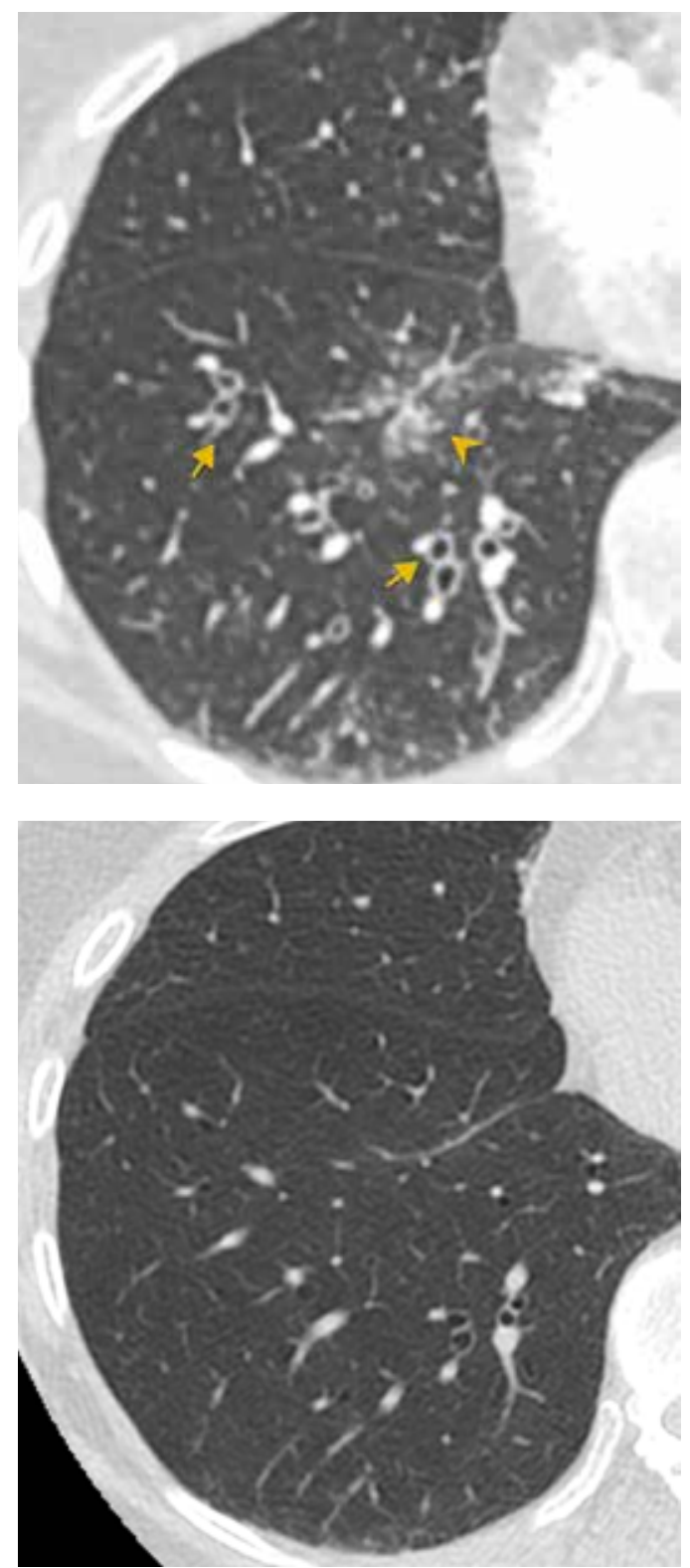

Mynd 3a-b. Berkjuskúlk er samkvæmt skilgreiningu óviðsnúanleg berkjuvíkkun. Í vissum tilfellum getur væg viðsnúanleg berkjuvíkkun komið fram, til dæmis vegna berkjulungnabólgu. Dessi sjúklingur hafði einkenni neðri loftvegasýkingar. Tölvusneiðmyndin sýnir væga staðbundna víkkun á berkjum ásamt berkjuveggpykknunum og aðlægum lungnapéttingum. Eftir sýklalyfjameðferð hafa berkjuvíkkunin og lungnapéttingarnar gengið til baka. ${ }^{4}$ dóma. ${ }^{45}$ Áunninn eða afleiddur ónæmisbrestur sést í vaxandi mæli hjá eldri einstaklingum. ${ }^{46}$ Einkum er um að ræða einstaklinga sem hafa verið á sterameðferð í lengri tíma, sem veldur skorti á mótefnum af IgG-gerð eða undirflokkum peirra. Pá getur önnur meðferð valdið skorti á mótefnum en oft eru orsakir fyrir mótefnaskorti ópekktar.

\section{Svipgerðir berkjuskúlks}

Vegna pess að berkjuskúlk á sér margar orsakir og sjúkdómsmyndir er vaxandi áhugi fyrir pví að finna svipgerðir sjúkdómsins sem hjálpað gætu við að bæta meðferð. Nýlega birtust niðurstöður rannsókna par sem hægt var að greina fjórar mismunandi svipgerðir hjá sjúklingum með berkjuskúlk. ${ }^{47}$ pær byggðust á sýklarannsóknum og klínískum einkennum. Fyrsta svipgerðin er sú að hafa langvinna Pseudomonas-sýkingu (16\%), önnur að hafa aðra langvinna sýkingu (24\%), priðja að hafa daglegan hósta (33\%) og fjórða að hafa purrt berkjuskúlk (án slímuppgangs, 27\%). Peir sem voru með langvinna Pseudomonas-sýkingu höfðu fleiri versnanir, voru oftar lagðir inn á sjúkrahús og höfðu meiri merki um bólgu. Dánartíðni peirra var hærri og lífsgæði voru lakari. Peim sem voru með purrt berkjuskúlk farnaðist best.

\section{Rannsóknir}

Mikilvægt er að аð leita að undirliggjandi orsökum berkjuskúlks og finna má orsakir í yfir 50\% tilvika og pannig stuðla að markvissari meðferð. Hægt er að gera fjöldamargar rannsóknir til að greina orsakir vegna pess hvað pær geta verið margvíslegar eins og sést í töflu I. Ýmis atriði er hægt að styðjast við til pess að gera slíka uppvinnslu hnitmiðaðri. Pannig geta eldri tölvusneiðmyndir verið hjálplegar sem og saga um fyrri lungnasýkingar. Pá getur dreifing og útlit breytinga á tölvusneiðmynd hjálpað til. Sem dæmi gæti berkjuskúlk sem er eingöngu í neðra blaði hægra lunga bent til aðskotahlutar sem orsakar og fyrsta rannsókn verið berkjuspeglun fremur en blóð- og aðrar rannsóknir til að leita að meðfylgjandi sjúkdómi. ${ }^{4}$

\section{Röntgenmyndir af brjóstholi}

Röntgenmyndir af brjóstholi hafa lítið næmi í greiningu og eftirliti á berkjuskúlki en geta verið hjálplegar í byrjun til að útiloka aðrar orsakir einkenna sem geta líkst berkjuskúlki. Pær geta einnig nýst til að greina breytingar ef koma versnanir. ${ }^{48}$

\section{Tölvusneið̃myndir af brjóstholi}

Tölvusneiðmyndir af lungum greina berkjuskúlk, flokka niður í gerðir og segja til um meðfylgjandi sjúkdóma í lungum. Útvíkkun berkju er aðalskilmerkið og er fundið með pví að bera saman pvermál berkju við meðfylgjandi lungnaslagæð eins og sést á mynd 2. Almennt er miðað við að berkja sé útvíkkuð ef hlutfallið er meira en 1:1. Ýmsar lífeðlisfræðilegar eða sjúklegar ástæður geta haft áhrif á hlutfallið og pað eykur pví næmi að auka hlutfallið í meira en 1,5 á móti 1. Sem dæmi um eðlilega lífeðlisfræðilega skýringu á útvíkkun er öldrun og dæmi um sjúklegt ástand sem getur valdið berkjuútvíkkun er lungnahrun eða bólga, oftast vegna sýkingar eins og í lungnabólgu (mynd 3). Pannig er ekki hægt að greina við- 


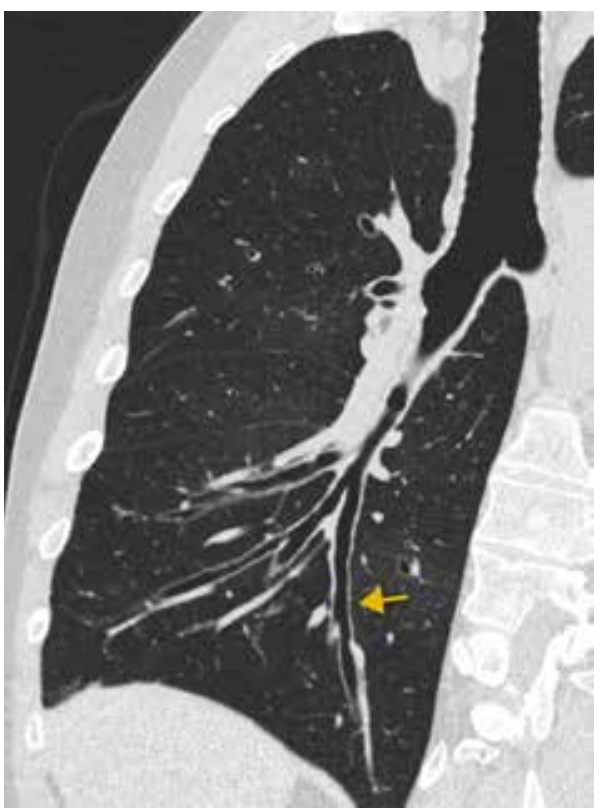

Mynd 4. Sívalt berkjuskúlk. Enduruppbyggð mynd eftir lengdarási loftvega sýnir vöntun á mjókkun loftvega meira en $2 \mathrm{~cm}$ frá berkjugreiningu. Detta er næmasta myndteikn berkjuskúlks. ${ }^{4}$

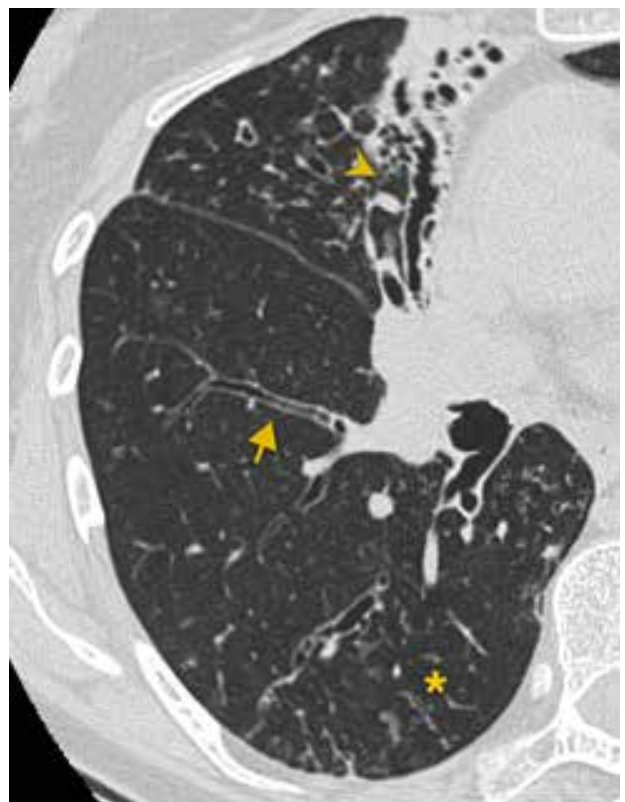

Mynd 5. Mismunandi tegundir berkjuskúlks geta sést í sama sjúklingi og hafa takmarkaða klíníska pýdingu. Myndin sýnir hnúta-berkjuskúlk i miðblaði (örvaoddur) og sívalt berkjuskúlk í hægra neðra lungnablaði. Trjábrumspéttingar koma einnig fram (stjarna) en pad er algengur tengdur myndfundur og bendir oftast til sýkingar. ${ }^{4}$

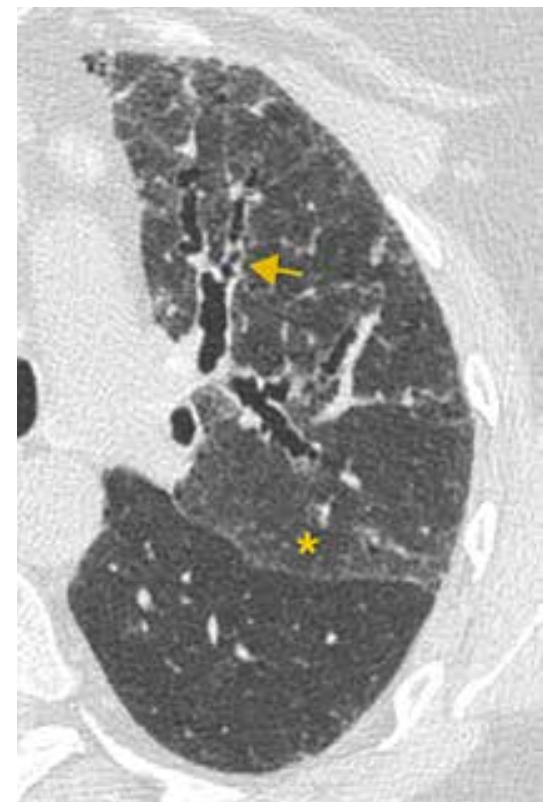

Mynd 6. Hnúta-berkjuskúlk (ör) hjá sjúklingi með sarklíki. Dreifingin í efri lungnablöðum er dæmigerð, oftast beggja vegna. Óregluleg skáglufa vinstra lunga (stjarna) gefur til kynna bandvefsmyndun. ${ }^{4}$ varandi berkjuskúlk meðan á sýkingu stendur og getur purft að endurtaka tölvusneiðmynd síðar til að staðfesta greiningu. ${ }^{4}$ Eðlilegir loftvegir mjókka eftir pví sem peir fara lengra útlægt en ef peir gera pað ekki yfir $2 \mathrm{~cm}$ vegalengd frá loftvegaskiptingu er pað merki um berkjuskúlk sem hefur mikið næmi og getur verið fyrsta teikn um sjúkdóminn (mynd 4). Ef berkjur sjást á tölvusneiðmynd í minna en eins cm fjarlægð frá rifjafleiðru eða alveg að miðmætisfleiðru er pað merki um berkjuskúlk.

Algengar tengdar breytingar sem sjást á tölvusneiðmyndum og tengjast bólgu eru berkjuveggspykknanir, slímtappar í berkjum og trjábrumspéttingar. ${ }^{4}$

Berkjuskúlki er skipt í prjár tegundir sem eru: 1. Sívalt berkjuskúlk sem er algengast. 2. Hnúta-berkjuskúlk par sem skiptast á útvíkkuð og inndregin svæði. 3. Blöðru-berkjuskúlk sem er versta gerðin og blöðrurnar eru gjarna með loftvökvaborði (mynd 2, 4, 5). Tölvusneiðmyndir geta hjálpað til við að greina orsakir berkjuskúlks. Dæmi um pað eru aðskotahlutir eða æxli í berkjum. Dreifing breytinga getur bent til ákveðinna orsaka. Pannig getur staðsetning í efri blöðum lungna bent til að orsökin sé slímseigjusjúkdómur, eldri berklasýking, sarklíki eða ástand eftir geislun (mynd 6,7). Staðsetning í neðri blöðum bendir til ásvelgingar, að fyrri sýking sé orsök eða vanstarfsemi á ónæmiskerfi. Staðsetning í fremri hlutum miðblaðs eða tynglu (lingula) getur bent til mýkóbakteríusýkingar sem ekki eru berklar (mynd 8 og 9$)^{4}$

\section{Lungnarannsóknir}

Lungnarannsóknir geta verið eðlilegar en geta einnig sýnt teppu, herpu eða blandaða mynd eftir pví hvort sjúkdómurinn tengist öðrum sjúkdómum eins og langvinnri lungnateppu og astma eða standi einn sér.

\section{Hrákarannsóknir}

Ræktun á hráka er mikilvæg til að greina bakteríur og mikilvægt er að gera berklaræktun í að minnsta kosti eitt skipti.

\section{Blóorrannsóknir}

Almennar blóðrannsóknir eru sjaldan hjálplegar til að greina orsakir. Hækkun á hvítum blóðkornum og bólguvísum eins og CRP getur hjálpað til við greiningu versnunar. Aukning á rauðkirningum í blóði getur hjálpað til við að finna pá sem gætu haft gagn af steralyfjum í innöndunarformi.

\section{Sérhæfðaar rannsóknir}

Fjöldamargar sérhæfðar rannsóknir geta hjálpað til við að greina meðfylgjandi sjúkdóma berkjuskúlks. ${ }^{1}$ Mikilvægt er að leita orsaka pess og meðfylgjandi sjúkdóma. Gigtarpróf í blóði eru mjög hjálpleg til að greina pá sem hafa gigtsjúkdóma. Rannsóknir á ónæmiskerfi geta greint ónæmisgalla. Pannig er hægt að mæla mótefni af gerð IgA, IgM og IgG ásamt undirflokkum IgG. Pá er mæling á IgE og fellimótefnum gegn Aspergillus-hluti af pví að greina ofnæmisviðbragð við könnusveppi (mynd 10). Mæling á mótefnum gegn pneumókokkum bæði fyrir og eftir bólusetningu hjálpar til við að meta virkni ónæmiskerfisins. Erfðarannsóknir og mælingar á alfa-1-antitrypsini í blóði greina skort á alfa-1-antitrypsini og svitapróf og erfðarannsóknir greina slímseigjusjúkdóm. Magaspegl- 


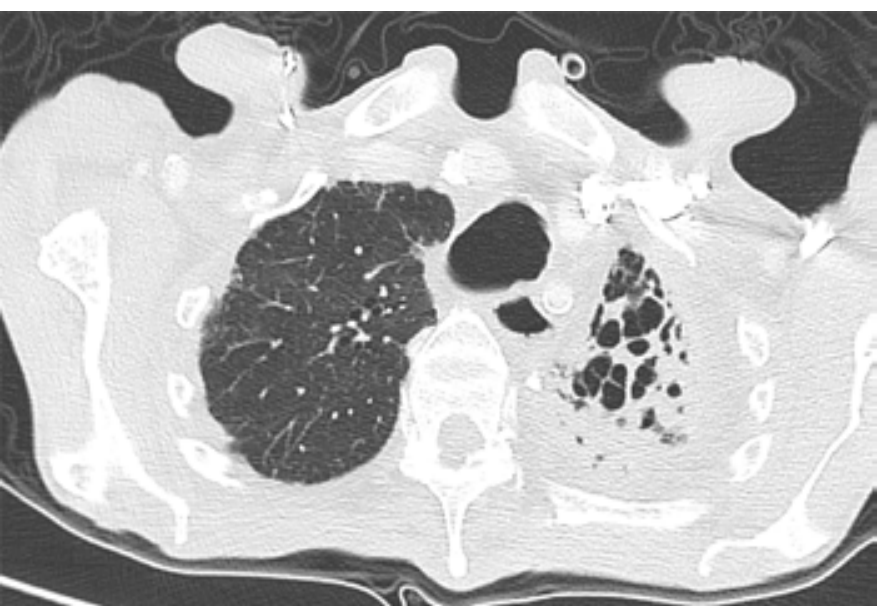

Mynd 7. Berkjuskúlk eftir berkla hjá eldri sjúklingi. Dreifing breytinga einhliða í lungnatoppi er dæmigerð. ${ }^{4}$

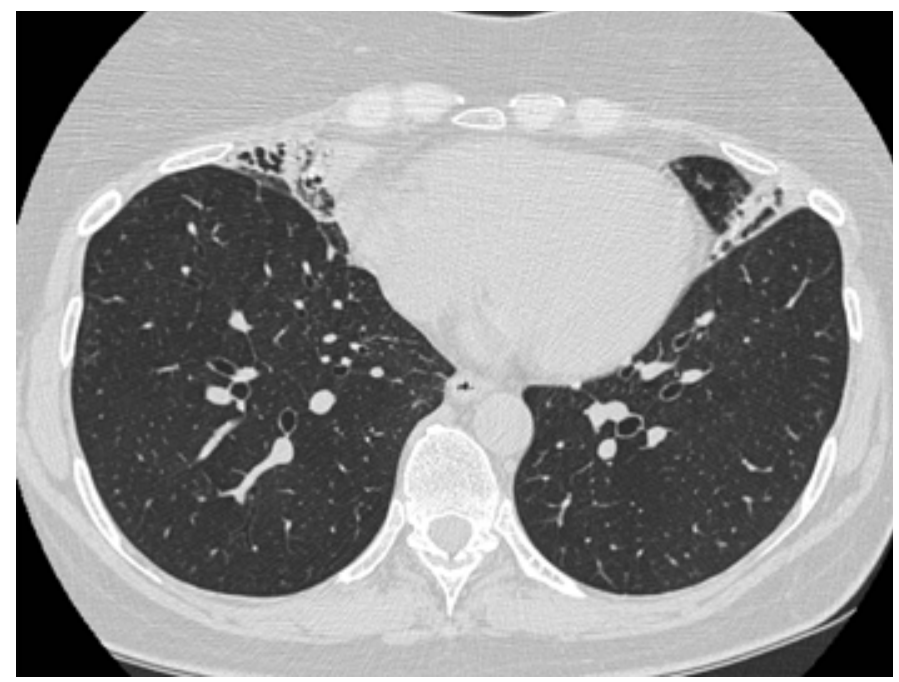

Mynd 8. Berkjuskúlk i miðblaði og tynglu vegna mýkóbaktería sem ekki eru berklar (mycobacterium avium-intracellulare). ${ }^{4}$

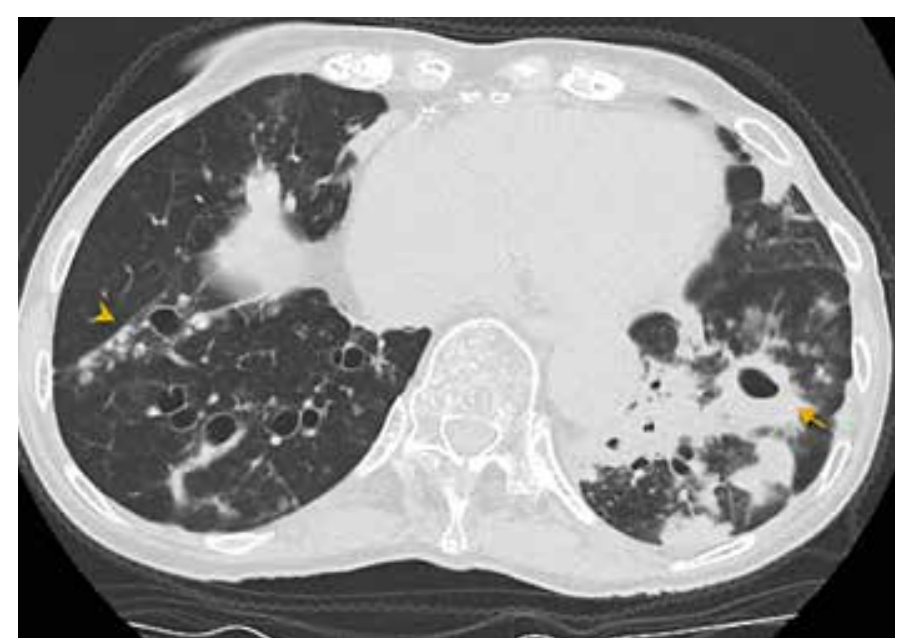

Mynd 9. Berkjuskúlk vegna mýkóbaktería sem ekki eru berklar (mycobacterium aviumintracellulare) hjá öðrum sjúklingi. Beggja vegna sést sívalt berkjuskúlk ásamt dreifðum smáum hnútum (örvaoddur), sumir hnútanna innihalda kalkanir. Lungnapéttingar með holmyndun sjást einnig í neðra vinstra lungnablaði (ör). ${ }^{4}$ un greinir vélindabakflæði, pindarslit og prengingar í vélinda. Kyngingarmynd talmeinafræðings greinir ásvelgingu og röntgenmynd af vélinda með skuggaefni greinir prengingar. Ristilspeglun og fleiri rannsóknir greina bólgusjúkdóma í meltingarvegi.

\section{Berkjuspeglun}

Aðaltilgangur berkjuspeglunar er að greina aðskotahluti sem gæu hafa komið ferlinu af stað. Pá er oftast um að ræða staðbundið berkjuskúlk frekar en dreift og oft sést samfall á hluta af lunga um leið. Annar tilgangur berkjuspeglunar væri að fá skolsýni hjá peim sem hafa lítinn uppgang en tíðar versnanir. Pá er bæði hægt að fá sýni til ræktunar en einnig að meta frumur sem koma fram í skoli. Mikill fjöldi rauðkirninga gæti bent til gagnsemi sterameðferðar.

\section{Versnanir á einkennum}

Algengt er að sjúklingar með berkjuskúlk finni fyrir versnun einkenna. Pannig fá peir aukinn hósta og uppgang sem getur pykknað og breytt um lit. Pá getur fylgt blóðhósti. Almenn einkenni geta verið til staðar eins og slappleiki, lystarleysi og hiti. Pessu fylgir aukin bólga í berkjum og kerfisbundin bólga. Ekki er til nein ákveðin alpjóðleg skilgreining á versnunum á berkjuskúlki. Pannig hafa mismunandi lönd og sérgreinafélög komið fram með mismunandi skilgreiningar. Oftast er gert ráð fyrir auknum einkennum og einnig parf að koma til breyting á meðferð til að pað teljist versnun.

Árið 2016 var sett fram alpjóðleg tillaga um skilgreiningu á versnun. ${ }^{49}$ Par var stungið upp á pví að til kæmi breyting á meðferð í tengslum við breytingar á að minnsta kosti premur einkennum á síðustu 48 klukkustundum. Pessi einkenni eru hósti, magn og/ eða pykkt uppgangs, litur á hráka, mæði, slappleiki og blóðhósti. Аð jafnaði eru versnanir taldar stafa af sýkingum sem orsakaðar eru af bakteríum. Petta er pó ekki vel rannsakað og margt óljóst. Jafnvel er talið að aukin íferð daufkirninga í berkjur án sýkingar geti komið af stað versnun. Aðrar orsakir eru ekki vel rannsakaðar og ekki heldur páttur hjásjúkdóma í versnunum.

Pekkt eru tengsl milli loftmengunar og versnandi einkenna berkjuskúlks. Pannig getur loftmengun aukið á bólgusvörun í berkjum, bælt ónæmissvörun og valdið truflunum á líffilmu berkjanna. Pekktur hjásjúkdómur í berkjuskúlki er vélindabakflæði sem tengt hefur verið aukinni tíðni versnana. ${ }^{50}$ Versnanir á berkjuskúlki eru mikilvægar pví pær valda auknum kostnaði í heilbrigðiskerfinu og pær eru tengdar vaxandi lungnaskemmdum, skerðingu á lífsgæðum, hraðari skerðingu á lungnastarfsemi og aukinni dánartíðni. ${ }^{47}$ Líkt og í öðrum lungnasjúkdómum hefur verið vaxandi áhugi á að finna pá sem hafa tíðar versnanir til að reyna að fyrirbyggja pær og draga úr áhrifum peirra á sjúklinginn. Ekki er til ákveðin skilgreining á tíðum versnunum en margir miða við prjár eða fleiri á ári. ${ }^{6}$ Helsti áhættupáttur er fjöldi versnana árið á undan. Pá eru langvinnar sýkingar með P. aeruginosa sterkur áhættupáttur. Tíðar versnanir hafa enn meiri áhrif á lífsgæði, dánartíðni og sjúkrahúsinnlagnir en færri eða engar versnanir. 

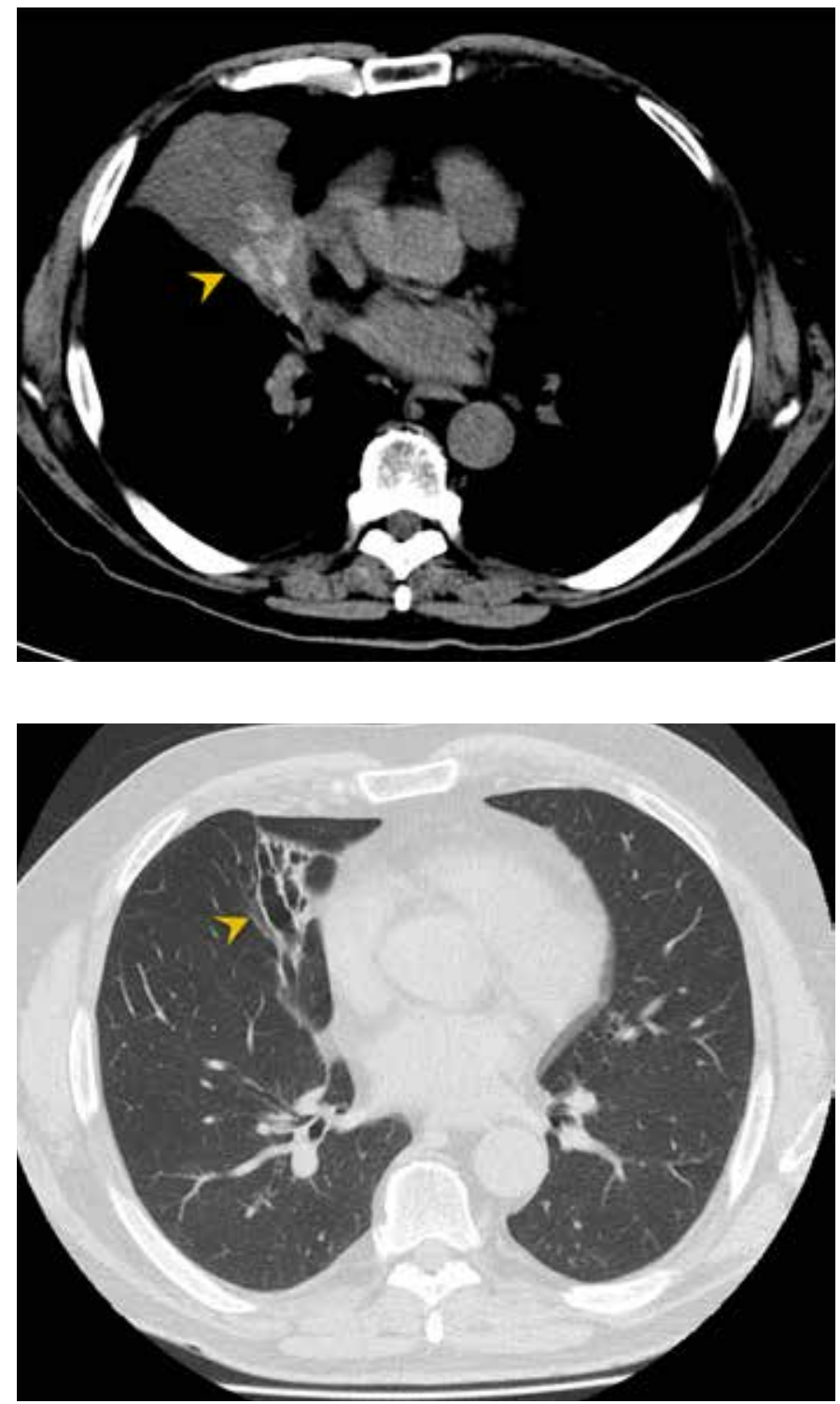

Mynd 10ab. Berkjuskúlk vegna ofnæmisviðbragðs við könnusveppi (ABPA). Astmasjúklingur með priggja mánaða sögu um hósta með uppgangi. Hrákasýni sýndi aspergillus-sveppi. Rauðkirningar voru hækkaðir í blóði ásamt IgE-mótefnum og fellimótefnum gegn Aspergillus. Tölvusneiðmynd sýnir hápétta slímtappa í víkkuðum berkjum (örvaoddur), dæmigert fyrir ABPA, ásamt lungnahruni. Endurtekin tölvusneiðmynd eftir meðferð með sveppalyfjum og sterum sýnir brotthvarf slímtappa með eftirstandandi berkjuskúlki (örvaoddur). ${ }^{4}$

\section{Meðferð}

Meðferð berkjuskúlks felst í pví að meðhöndla undirliggjandi sjúkdóma, draga úr sýkingum og auka loftvegahreinsun (mynd 10). Petta bætir lífsgæði, dregur úr frampróun sjúkdómsins og fækkar versnunum.

\section{Meðferð̃ sýkinga}

Sýkingar eru stór hluti af sjúkdómsmynd berkjuskúlks. Meðferð peirra er pví mikilvægur hluti af meðferð berkjuskúlks. Til að meðferðin verði sem áhrifaríkust er vandað hrákasýni pví mikilvægt svo hægt sé að greina um hvaða bakteríu sé að ræða og hvert næmi hennar fyrir sýklalyfjum er. ${ }^{1}$ Sýklalyfjameðferð er svo valin út frá niðurstöðum hrákaræktunar eða peim upplýsingum sem fyrir liggja um tíðni bakteríusýkinga í samfélaginu. Að jafnaði eru sýklalyf gefin í lengri tíma en almennt er gert við öndunarfærasýkingar. Oftast er miðað við tvær vikur. ${ }^{51}$

\section{Langtíma sýklalyfjameðferð}

Pegar um er аð ræða endurteknar versnanir eru sýklalyf gefin lengur en prjá mánuði í senn. ${ }^{1}$ Pannig er hægt að fækka versnunum og í mörgum tilvikum bæta lífsgæði. ${ }^{6}$ Algengast er að nota azitrómýcín 250-500 mg prisvar í viku en pað má einnig nota sýklalyf af tetrasýklín-flokki. ${ }^{52}$

\section{Leið sýklalyfja}

Sýklalyf eru í langflestum tilvikum gefin um munn. Í sumum tilvikum eru bakteríur ónæmar fyrir sýklalyfjum sem hægt er að gefa um munn og í öðrum tilvikum eru aukaverkanir frá meltingarvegi sem koma í veg fyrir gjöf peirra um munn. Pá kemur til greina sýklalyfjameðferð í æð ef næmi er til staðar. Einnig er hægt að gefa sýklalyf í innöndun rétt eins og berkjuvíkkandi lyf og innöndunarstera. Pá fæst verkun beint á peim stað sem sýkingin er og par með minni aukaverkanir.

Árið 2019 birtist safngreining á virkni og og öryggi sýklalyfja sem gefin eru með innöndun. ${ }^{53}$ Í flestum rannsóknunum var $P$. aeruginosa algengasta bakterían sem var meðhöndluð en sjúklingarnir voru einnig með aðrar bakteríur. Að jafnaði poldust slík sýklalyf vel og pau fækkuðu bakteríum í berkjum og drógu úr tíðni versnana en bættu ekki lífsgæði.

Almennt eru pessi sýklalyf ekki gefin nema búið sé að reyna sýklalyf um munn og pau polast ekki eða halda versnunum ekki frá.

\section{Slímlosandi meðferð}

Slímlosandi lyfjameðferð eykur líkur á að losa upp slím og dregur úr slímmyndun. ${ }^{54}$ Slík lyf má setja í fjóra flokka. Í fyrsta lagi eru lyf sem auka líkur á að slím komi upp úr berkjunum pegar hóstað er. Dæmi um petta er háprýstið saltvatn (hypertonic saline). Í öðru lagi eru lyf sem hafa áhrif á stjórnun slímmyndunar og dæmi eru andkólínvirk lyf. Í priðja flokki eru lyf sem hafa áhrif á seigju slíms. Dæmi um pau lyf eru N-asetýlcystein og DNAasi. Í fjórða lagi er um að ræða lyf sem hafa áhrif á bifhár og auka pannig á hreinsun slíms. Dæmi eru berkjuvíkkandi lyf. Ekkert af pessum lyfjum fækkar versnunum og DNAasi fjölgar peim. Pað er pví ekki mælt með DNAasa lyfjum hjá sjúklingum með berkjuskúlk. ${ }^{1}$ Almennt eru tiltölulega fáar rannsóknir til um notagildi slímlosandi lyfja. ${ }^{1}$ Mikilvægt er að pessi lyf séu notuð í tengslum við loftvegahreinsun. Pannig hefur háprýstið saltvatn skamman virknitíma og pví mikilvægt að loftvegahreinsun sé gerð í framhaldi af slíkri lyfjagjöf. ${ }^{54}$ 


\section{Loftvegahreinsun}

Með loftvegahreinsun er átt við aðferðir sem hreinsa loftvegina en eru ekki lyfjameðferð. ${ }^{54}$ Pær draga úr einkennum, bæta lífsgæði og draga úr tíðni versnana. ${ }^{55}$ Mikilvægt er að allir sjúklingar með berkjuskúlk fái pjálfun og kennslu í loftvegahreinsun. Algengt er að sjúkrapjálfarar veiti pessa pjálfun. Margar gerðir af loftvegahreinsun geta sjúklingar gert án utanaðkomandi aðstoðar en sumar gerðir purfa utanaðkomandi aðstoð. ${ }^{56}$ Rannsóknir benda til pess að innan við helmingur sjúklinga með berkjuskúlk nýti sér loftvegahreinsun reglulega. ${ }^{57}$ Lífeðlisfræðilega byggir loftvegahreinsun á tveimur páttum sem skarast. ${ }^{54}$ Í fyrsta lagi að loft komist bak við hindrunina í berkju og pannig verði loftskipti handan við hindrunina. Í öðru lagi að breytingar á flæði í útöndun hreyfi slím nærlægt í berkjurnar. Loftvegahreinsun sem sjúklingar geta gert sjálfir felst í fyrsta lagi í stöðubundinni losun par sem sjúklingur lætur höfuð og efri hluta líkama liggja lægra en neðri hluta og við pað flyst slím betur nærlægt í berkjur og kemur jafnvel upp úr peim. Í öðru lagi eru notaðar svokallaðar virkar hringrásar öndunaraðferðir (active cycle of breathing methods). Pær felast í pví að hafa stjórn á öndun, æfingum par sem andað er djúpt og æfingum par sem beitt er hraðri útöndun. Einnig eru til tæki par sem andað er frá sér gegn jákvæðum útöndunarprýstingi með sveiflu (oscillation). Рað hjálpar slími að færast nærlægt í berkjur og hröð útöndun með hósta kemur slími alla leið í munn. ${ }^{54}$ Engin ein af pessum aðferðum er betri en önnur og pær eru gjarna notaðar saman eftir pví sem sjúklingi líkar best og hann hefur mest gagn af. ${ }^{58}$

\section{Lungnaendurhæfing}

Lungnaendurhæfing getur gagnast sjúklingum með berkjuskúlk. Klínískar leiðbeiningar mæla með endurhæfingu fyrir pá sem eru mæðnir. ${ }^{1}$ Lungnaendurhæfing er pverfagleg og kemur pví víða við. Sjúkrapjálfarar kenna tækni sem stuðlar að loftvegahreinsun. Veitt er fræðsla um sjúkdóminn, meðferð við honum og gefnar eru leiðbeiningar um rétta líkamspjálfun. ${ }^{54}$ Rannsóknir hafa sýnt að lungnaendurhæfing hefur góð áhrif til styttri tíma en áhrif til lengri tíma eru ekki eins góð.59

\section{Önnur meðferð Innöndunarlyf}

Innöndunarsterar eru gefnir peim sem hafa undirliggjandi loftvegasjúkdóm eins og astma og langvinna lungnateppu. ${ }^{1}$ Langvirk berkjuvíkkandi lyf henta peim sem eru mæðnir, einkum við áreynslu.

\section{Gammaglobúlín-meðferð}

Ef um er að ræða meðfæddan skort á mótefnum er gefin uppbótarmeðferð með gammaglobúlínum. ${ }^{6}$ Við áunninn ónæmisbrest með lækkuðum gildum á IgG og/eða undirflokkum kemur uppbótarmeðferð til greina hjá peim sem sýna skerta mótefnamyndun við pneumókokka-bólusetningu og svara ekki vel langtíma sýklalyfjameðferð.

\section{Skurðaðgerðir}

Ef berkjuskúlk er staðbundið í einu blaði lunga og veldur miklum einkennum eins og til dæmis tíðum öndunarfærasýkingum sem skerða lífsgæði sjúklings, kemur til greina að fjarlægja blaðið með skurðaðgerð. Árið 2009 birtist grein sem lýsti greiningu og meðferð 18 sjúklinga á Íslandi sem farið höfðu í brottnám á miðblaði hægra lunga vegna endurtekinna sýkinga ${ }^{60}$ Af peim voru 7, eða $39 \%$, með berkjuskúlk á tölvusneiðmynd. Við skoðun vefjasýna reyndist helmingur hafa berkjuskúlk.

\section{Meðferð bráðra versnana}

Ef sjúklingur er með berkjuskúlk tengt öðrum sjúkdómum í brjóstholi er meðferð versnunar eins og klínískar leiðbeiningar um undirliggjandi sjúkdóma segja til um. ${ }^{1}$ Pannig eru sterar, sýklalyf og berkjuvíkkandi lyf gefin peim sem hafa undirliggjandi astma eða langvinna lungnateppu. Sterar og berkjuvíkkandi lyf gagnast eingöngu peim sem hafa undirliggjandi teppusjúkdóm í lungum og eru ekki gefin peim sem ekki hafa pessa sjúkdóma. Sýklalyf eru mikilvægur páttur í meðferð bráðra versnana. Ræktun á hrákasýni getur hjálpað til við að greina um hvaða bakteríur sé að ræða. Einnig geta niðurstöður fyrri hrákasýna verið leiðbeinandi um hvaða sýklalyf væri rétt að nota. Klínískar leiðbeiningar ráðleggja að sýklalyf séu gefin í lengri tíma en að jafnaði við öndunarfærasýkingar. ${ }^{1,6}$ Pannig er almennt mælt með gjöf peirra í 14 daga. ${ }^{51}$ Pá getur aukin loftvegahreinsun verið gagnleg meðan á bráðri versnun stendur. Mælt er með daglegri aðstoð sjúkrapjálfara hjá peim sem leggjast inn á sjúkrahús. Almennri stuðningsmeðferð er einnig beitt, eins og súrefnisgjöf og öndunarvélameðferð ef pörf krefur. Blóðhósti getur verið eitt af einkennum versnana. Ef um er að ræða mikið magn er sjúklingur lagður inn á sjúkrahús. Gefin eru sýklalyf í æð og gengið úr skugga um að blóðstorknun sé eðlileg. Pá eru öll blóðpynnandi lyf stöðvuð. Ef petta dugar ekki geta röntgenlæknar með inngripi lokað lungnaslagæðum til svæðis sem blæðing kemur frá.

\section{Eftirlit}

Mælt er með pví að gera sýklaræktun frá hráka að minnsta kosti einu sinni á ári í stöðugu ástandi og pegar að einkenni versna. ${ }^{6}$ Að jafnaði er líka gerð berklaræktun. Peir sem eru með alvarlegra form ættu að vera í eftirliti hjá læknum með sérpekkingu á berkjuskúlki til viðbótar við heimilislækni.

\section{Framtídin}

Mikilvægt er að greina berkjuskúlk eins fljótt og hægt er til pess að hægt sé að veita rétta meðferð sem getur rofið pann vítahring sem oft er til staðar hjá sjúklingum með berkjuskúlk. Pá er mikilvægt að finna lífvísa sem geta sagt til um frampróun sjúkdómsins. Betri greiningar á sýklafræði myndu vanda enn frekar notkun sýklalyfja og vöntun er á meðferð við loftvegabólgunni sem er til staðar og einkennist af daufkirningum. 


\section{Lokaord}

Berkjuskúlk er sjúkdómur sem einkennist af útvíkkuðum berkjum. Mikilvægt er að læknar hafi berkjuskúlk í huga pegar peir standa frammi fyrir sjúklingum með langvinnan hósta með eða án slímuppgangs og sögu um endurteknar öndunarfærasýkingar. Greining fæst með tölvusneiðmynd af brjóstholi og ítarlegri rannsóknir geta leitt til greiningar undirliggjandi sjúkdóma par sem sérhæfð meðferð dregur úr áhrifum sjúkdómsins á berkjurnar. Meðferðin er fólgin í pví að meðhöndla meðfylgjandi sjúkdóm, gefa sýklalyf til lengri eða skemmri tíma og stuðla að loftvegahreinsun. Pá er lungnaendurhæfing og regluleg líkamspjálfun mikilvæg eins og í öðrum langvinnum lungnasjúkdómum.

\section{Greinin barst til blaðsins 21. mars 2020, sampykkt til birtingar 18. júní 2020.}

\section{Heimildir}

1. Hill AT, Sullivan AL, Chalmers JD, et al. British Thoracic Society Guideline for bronchiectasis in adults. Thorax 2019; 74 (Suppl 1): 1-69.

2. Lesan A, Lamle AE. Short review on the diagnosis and treatment of bronchiectasis. Med Pharm Rep 2019; 92: 111-6.

3. Boucher RC. Muco-Obstructive Lung Diseases. N Engl J Med 2019; 380: 1941-53.

4. Juliusson G, Gudmundsson G. Diagnostic imaging in adult $\square$ non-cystic fibrosis bronchiectasis. Breathe (Sheff) 2019; 15: 190-7.

5. Flume PA, Chalmers JD, Olivier KN. Advances in bronchiectasis: endotyping, genetics, microbiome, and disease heterogeneity. Lancet 2018; 392: 880-90.

6. Polverino E, Goeminne PC, McDonnell MJ, et al. European Respiratory Society guidelines for the management of adult bronchiectasis. Eur Respir J 2017; 50: 1700629.

7. Kocurek EG, Jagana R. Noncystic fibrosis bronchiectasis management: opportunities and challenges. Curr Opin Pulm Med 2019; 25: 192-200.

8. Chalmers JD, Elborn JS. Reclaiming the name 'bronchiectasis'. Thorax 2015; 70: 399-400.

9. Lonni S, Chalmers JD, Goeminne PC, et al. Etiology of Non-Cystic Fibrosis Bronchiectasis in Adults and Its Correlation to Disease Severity. Ann Am Thorac Soc 2015; 12: 1764-70.

10. Chalmers JD, Sethi S. Raising awareness of bronchiectasis in primary care: overview of diagnosis and management strategies in adults. NPJ Prim Care Respir Med 2017; $27: 18$.

11. Quint JK, Millett ER, Joshi M, et al. Changes in the incidence, prevalence and mortality of bronchiectasis in the UK from 2004 to 2013: a population-based cohort study. Eur Respir J 2016; 47: 186-93.

12. Snell N, Gibson J, Jarrold I, et al. Epidemiology of bronchiectasis in the UK: Findings from the British lung foundation's 'Respiratory health of the nation' project. Respir Med 2019; 158: 21-3.

13. Quint JK, Smith MP. Paediatric and adult bronchiectasis: Diagnosis, disease burden and prognosis. Respirology 2019; 24: 413-22.

14. Aliberti S, Sotgiu G, Lapi F, et al. Prevalence and incidence of bronchiectasis in Italy. BMC Pulm Med 2020; 20: 15.

15. Cole PJ. Inflammation: a two-edged sword--the model of bronchiectasis. Eur J Respir Dis Suppl 1986; 147: 6-15.

16. Gramegna A, Amati F, Terranova L, et al. Neutrophil elastase in bronchiectasis. Respir Res 2017; 18: 211.

17. Dente FL, Bilotta M, Bartoli ML, et al. Neutrophilic Bronchial Inflammation Correlates with Clinical and Functional Findings in Patients with Noncystic Fibrosis Bronchiectasis. Mediators Inflamm 2015; 2015: 642503.

18. Bedi P, Davidson DJ, McHugh BJ, et al. Blood Neutrophils Are Reprogrammed in Bronchiectasis. Am J Respir Crit Care Med 2018; 198: 880-90.

19. Watt AP, Brown V, Courtney J, et al. Neutrophil apoptosis, proinflammatory mediators and cell counts in bronchiectasis. Thorax 2004; 59: 231-6.

20. Amati F, Simonetta E, Gramegna A, et al. The Biology of Pulmonary Exacerbations in Bronchiectasis. Eur Respir Rev 2019; 28: 190055.

21. Chalmers JD, Moffitt KL, Suarez-Cuartin G, et al. Neutrophil Elastase Activity Is Associated with Exacerbations and Lung Function Decline in Bronchiectasis. Am J Respir Crit Care Med 2017; 195: 1384-93.

22. Norman AW. From vitamin D to hormone D: fundamentals of the vitamin D endocrin system essential for good health. Am J Clin Nutr 2008; 88: 491S-9S

23. Wang TT, Nestel FP, Bourdeau V, et al. Cutting edge: 1,25-dihydroxyvitamin D3 is a direct inducer of antimicrobial peptide gene expression. J Immunol 2004; 173: 2909-12.

24. Chalmers JD, McHugh BJ, Docherty C, et al. Vitamin-D deficiency is associated with chroni bacterial colonisation and disease severity in bronchiectasis. Thorax 2013; 68: 39-47.

25. Amati F, Franceschi E, Gramegna A, et al. Investigating the Etiology of Bronchiectasis: You Do Not Find What You Do Not Look For. Respiration 2017; 93: 228-9.

26. Altenburg J, Wortel K, van der Werf TS, et al. Non-cystic fibrosis bronchiectasis: clinical presentation, diagnosis and treatment, illustrated by data from a Dutch Teaching Hospital. Neth J Med 2015; 73: 147-54.

27. Borekci S, Halis AN, Aygun G,et al. Bacterial colonization and associated factors in patients with bronchiectasis. Ann Thorac Med 2016; 11: 55-9.

28. Dimakou K, Triantafillidou C, Toumbis M, et al. P. Non CF-bronchiectasis: Aetiologic approach, clinical, radiological, microbiological and functional profile in 277 patients. Respir Med 2016; 116: 1-7

29. McDonnell MJ, Jary HR, Perry A, et al. Non cystic fibrosis bronchiectasis: A longitudinal retrospective observational cohort study of Pseudomonas persistence and resistance. Respir Med 2015; 109: 716-26.

30. Guan WJ, Gao YH, Xu G, et al. Aetiology of bronchiectasis in Guangzhou, southern China. Respirology 2015; 20: 739-48.

31. Aksamit TR, O'Donnell AE, Barker A, et al. Adult Patients With Bronchiectasis: A First Look at the US Bronchiectasis Research Registry. Chest 2017; 151: 982-92

32. Tunney MM, Einarsson GG, Wei L, et al. Lung microbiota and bacterial abundance in patients with bronchiectasis when clinically stable and during exacerbation. Am J Respir Crit Care Med 2013; 187: 1118-26.
33. Gao YH, Guan WJ, Xu G, et al. The role of viral infection in pulmonary exacerbations of bronchiectasis in adults: a prospective study. Chest 2015; 147: 1635-43.

34. Barb JJ, Oler AJ, Kim HS, Chalmers N, Wallen GR, Cashion A, et al. Development of an Analysis Pipeline Characterizing Multiple Hypervariable Regions of 16S rRNA Using Mock Samples. PLoS One 2016; 11: e0148047.

35. Cox MI, Turek EM, Hennessy C, et al. Longitudinal assessment of sputum microbiome by sequencing of the $16 \mathrm{~S}$ rRNA gene in non-cystic fibrosis bronchiectasis patients. PLoS One 2017; 12: e0170622

36. Gao YH, Guan WJ, Liu SX, et al. Aetiology of bronchiectasis in adults: A systematic literature review. Respirology 2016; 21: 1376-83.

37. Rogliani P, Sforza M, Calzetta L. The impact of comorbidities on severe asthma. Curr Opin Pulm Med 2020; 26: 47-55. pulmonary disease with comorbid bronchiectasis: a systemic review and meta-analysis. Int J Chron Obstruct Pulmon Dis 2015; 10: 1465-75.

39. Gramegna A, Aliberti S, Seia M, et al. When and how ruling out cystic fibrosis in adult patients with bronchiectasis. Multidiscip Respir Med 2018; 13 (Suppl 1): 29.

40. Agarwal R, Chakrabarti A, Shah A, et al. Allergic bronchopulmonary aspergillosis: review of literature and proposal of new diagnostic and classification criteria. Clin Exp Allergy 2013; 43: 850-73.

41. Perry E, Eggleton P, De Soyza A, Hutchinson D, Kelly C. Increased disease activity, severity and autoantibody positivity in rheumatoid arthritis patients with co-existent bronchiectasis. Int J Rheum Dis 2017; 20: 2003-11.

42. Andonopoulos AP, Yarmenitis S, Georgiou P, et al. Bronchiectasis in systemic sclerosis. A study using high resolution computed tomography. Clin Exp Rheumatol 2001; 19: 187-90.

43. Black H, Mendoza M, Murin S. Thoracic manifestations of inflammatory bowel disease. Chest 2007; 131: 524-32.

44. Honarbakhsh S, Taylor GP. High prevalence of bronchiectasis is linked to HTLV-1associated inflammatory disease. BMC Infect Dis 2015; 15: 258.

45. Bonilla FA, Khan DA, Ballas ZK, et al. Practice parameter for the diagnosis and management of primary immunodeficiency. J Allergy Clin Immunol 2015; 136: 1186-205. e1-78.

46. Dhalla F, Misbah SA. Secondary antibody deficiencies. Curr Opin Allergy Clin Immunol 2015; 15: 505-13

47. Aliberti S, Lonni S, Dore S, et al. Clinical phenotypes in adult patients with bronchiectasis. Eur Respir J 2016; 47: 1113-22.

48. van der Bruggen-Bogaarts BA, van der Bruggen HM, van Waes PF, Lammers JW. Screening for bronchiectasis. A comparative study between chest radiography and high-resolution CT. Chest 1996; 109: 608-11.

49. Hill AT, Haworth CS, Aliberti S, et al. Pulmonary exacerbation in adults with bronchiectasis: a consensus definition for clinical research. Eur Respir J 2017; 49: 1700051.

50. McDonnell MJ, Aliberti S, Goeminne PC, et al. Comorbidities and the risk of mortality in patients with bronchiectasis: an international multicentre cohort study. Lancet Respir Med 2016; 4: 969-79.

51. Somayaji $\mathrm{R}$, Goss $\mathrm{CH}$. Duration of antibiotic therapy in non-cystic fibrosis bronchiectasis. Curr Pulmonol Rep 2019; 8: 160-5.

52. Laska IF, Chalmers JD. Treatment to prevent exacerbations in bronchiectasis: macrolides as first line? Eur Respir J 2019; 54: 1901213

53. Laska IF, Crichton ML, Shoemark A, et al. The efficacy and safety of inhaled antibiotics for the treatment of bronchiectasis in adults: a systematic review and meta-analysis. Lancet Respir Med 2019; 7: 855-69.

54. O'Neill K, O'Donnell AE, Bradley JM. Airway clearance, mucoactive therapies and pulmonary rehabilitation in bronchiectasis. Respirology 2019; 24: 227-37.

55. Tambascio J, de Souza HCD, Martinez R, Baddini-Martinez JA, Barnes PJ, Gastaldi AC Effects of an Airway Clearance Device on Inflammation, Bacteriology, and Mucus Transport in Bronchiectasis. Respir Care 2017; 62: 1067-74.

56. Main E, Grillo L, Rand S. Airway clearance strategies in cystic fibrosis and non-cystic fibrosis bronchiectasis. Semin Respir Crit Care Med 2015; 36: 251-66.

57. McCullough AR, Tunney MM, Stuart Elborn J, at al. Predictors of adherence to treatment in bronchiectasis. Respir Med 2015; 109: 838-45.

58. Herrero-Cortina B, Vilaró J, Martí D, et al. Short-term effects of three slow expiratory airway clearance techniques in patients with bronchiectasis: a randomised crossover trial. Physiotherapy 2016; 102: 357-64.

59. Lee AL, Hill CJ, McDonald CF, et al. Pulmonary Rehabilitation in Individuals With NonCystic Fibrosis Bronchiectasis: A Systematic Review. Arch Phys Med Rehabil 2017; 98: 77482. e1.

60. Einarsson JT, Einarsson JG, Isaksson $\mathrm{H}$, et al. Middle lobe syndrome: a nationwide study on clinicopathological features and surgical treatment. Clin Respir J 2009; 3: 77-81.
38. Ni Y, Shi G, Yu Y, et al. Clinical characteristics of patients with chronic obstructive 


\title{
ENGLISH SUMMARY
}

\section{Bronchiectasis - a review}

Gunnar Gud̃mundsson ${ }^{1.2}$

Gunnar Júlíusson ${ }^{3}$

Key words: Bronchiectasis, review, treatment, medical imaging, microbiology.

Correspondence: Gunnar Guðmundsson, ggudmund@landspitali.is

'Department of Respiratory Medicine, National University Hospital, Reykjavik, Iceland, ${ }^{2}$ Faculty of Medicine, University of Iceland, Reykjavik, Iceland, ${ }^{3}$ Department of Radiology Karolinska University Hospital Stockholm, Sweden.
Bronchiectasis is a disease that is characterized by permanent bronchial dilation. This can be localized or diffuse in the lungs. The disease can occur at any age and causes cough, sputum production and repeated infections. It is more common in women and incidence increases with age.

Bronchiectasis is characterized by repeated episodes of worsening symptoms that are usually caused by respiratory infections.

The cause of bronchiectasis can be unknown but it can be caused by respiratory diseases and diseases outside the chest. Examples of such diseases are asthma, chronic obstructive pulmonary disease, rheumatoid arthritis in addition to immune deficiency. Disease profile is therefore different for each patient.

Bronchiectasis is diagnosed with computerized tomography of the chest in addition to clinical symptoms. Workup to diagnose other diseases that could be causing it is therefore important. For that detailed history, physical examination and additional investigations are appropriate.

Patients with bronchiectasis have decreased health related quality of life and increased mortality. Treatment focuses on treatment of underlying diseases, airway clearance and treatment of infections. Pulmonary rehabilititation is also important. Regular follow-up is important. This is a review on bronchiectasis that is intended for a spectrum of physicians, because bronchiectasis can be seen in primary care, hospitals and out of hospital.

Læknablaðið vill taka pátt í að útbúa og skrá upplýsingar,

reynslusögur, sjúkratilfelli og rannsóknir um faraldurinn.

\author{
Ritstjórn skorar á lækna í öllum sérgreinum að senda blaðinu \\ efni og rannsóknargreinar um faraldurinn hér heima.
}

Sendið efnið á netfangið ritstjorn@lis.is 